Article

\title{
Chitosan Inhibits Helicobacter pylori Growth and Urease Production and Prevents Its Infection of Human Gastric Carcinoma Cells
}

\author{
Shun-Hsien Chang ${ }^{1}$, Pei-Ling Hsieh ${ }^{2}$ and Guo-Jane Tsai ${ }^{2,3, *}$ \\ 1 Institute of Food Safety and Risk Management, National Taiwan Ocean University, Keelung 20224, Taiwan; \\ lewis@mail.ntou.edu.tw \\ 2 Department of Food Science, National Taiwan Ocean University, Keelung 20224, Taiwan; \\ peiling615@yahoo.com.tw \\ 3 Center for Marine Bioenvironment and Biotechnology, National Taiwan Ocean University, \\ Keelung 20224, Taiwan \\ * Correspondence: b0090@ntou.edu.tw; Tel.: +886-2-2462-2192 (ext. 5150); Fax: +886-2-2462-7954
}

Received: 13 October 2020; Accepted: 28 October 2020; Published: 29 October 2020

\begin{abstract}
This study investigated the effects of shrimp chitosan with $95 \%$ degree of deacetylation (DD95) in combination with clinical antibiotics on the growth and urease production of Helicobacter pylori. The inhibitory effect of DD95 on the adherence of $H$. pylori to the human intestinal carcinoma cells (TSGH9201) was also investigated. Five strains of H. pylori, including three standard strains and two strains of clinical isolates were used as the test strains. The inhibitory effects of DD95 on growth and urease production of various strains of $H$. pylori increased with increasing DD95 concentration and decreasing $\mathrm{pH}$ values from $\mathrm{pH} 6.0$ to $\mathrm{pH} 2.0$. Urease activity of $H$. pylori at $\mathrm{pH} 2.0$ in the presence of $4000 \mu \mathrm{g} / \mathrm{mL}$ of DD95 decreased by $37.86 \%$ to $46.53 \%$. In the presence of $50 \mu \mathrm{g} / \mathrm{mL}$ antibiotics of amoxicillin, tetracycline, or metronidazole at $\mathrm{pH} 6.0$ and $\mathrm{pH}$ 2.0, $\mathrm{H}$. pylori counts were decreased by $1.51-3.19$, and 1.47-2.82 Log CFU/mL, respectively. Following the addition of $4000 \mu \mathrm{g} / \mathrm{mL}$ DD95 into the $50 \mu \mathrm{g} / \mathrm{mL}$ antibiotic-containing culture medium with $\mathrm{pH} 6.0$ and $\mathrm{pH} 2.0$, overall $\mathrm{H}$. pylori counts were strongly decreased by 3.67-7.61 and 6.61-6.70 Log CFU/mL, respectively. Further, DD95 could inhibit the adherence of $H$. pylori on TSGH 9201 cells, as evidenced by fluorescent microscopy and thus may potentially protect against $H$. pylori infection.
\end{abstract}

Keywords: chitosan; antibacterial activity; Helicobacter pylori; urease activity; TSGH9201

\section{Introduction}

Epidemiological studies have found that Helicobacter pylori is closely associated with human gastrointestinal diseases, including chronic gastritis, gastric ulcer, duodenal ulcer, atrophic gastritis, mucosa-associated lymphoid tissue lymphoma, gastric cancer, and adenocarcinoma [1]. Over 50\% of population was infected by $H$. pylori [2] and approximately $6.2 \%$ of cancer cases reported worldwide is associated with H. pylori infection [3]. Treatment strategies using a single antibiotic plus a proton pump inhibitor (dual therapy) or two antibiotics plus a proton pump inhibitor or bismuth (triple therapy) have been adopted to eradicate H. pylori. The eradication rate for triple therapy using a proton pump inhibitor (operazole, lansoprazole) plus two antibiotics (e.g., amoxicillin [4], levofloxacin, metronidazole [5], or tetracycline [6]) is between 85 and 95\%. However, recently the eradication treatment efficacy of $H$. pylori has worsened [7]. The drawbacks result from a significant amount of side effects, low patient compliance, and drug resistance, or poor antibacterial effects of the antibiotic in a low $\mathrm{pH}$ environment and thus, this approach frequently results in treatment failure [8]. In particular, 
the therapeutic approach is not always completely curative; thus, alternative therapeutic agents are needed [8-10].

Chitosan, a partially deacetylated chitin (poly- $\beta-(1 \rightarrow 4) N$-acetyl-D-glucosamine) is a natural product found in shrimp, crab shells, and fungal cell wall. This polysaccharide and its derivatives have attracted attention as biomedical materials because of their good biodegradability [11], bioadhesion [12], and biocompatibility [13] properties with no observable immunogenicity, toxicity or side effects [14]. Given its excellent antibacterial activity, chitosan has been widely used for food preservation [15]. Several studies have shown that chitosan's molecular weight (MW) is a crucial factor of its antimicrobial properties. Our previous report concluded that the correlation between chitosan MW and its antibacterial properties was dependent on the $\mathrm{pH}$ value of the reaction mixture [16].

In this study, we prepared shrimp chitosan with 95\% deacetylation (DD95) and demonstrated that this preparation exerts strong antibacterial activity against $H$. pylori and effectively reduces urease activity of test strains. Combination of inhibitory effects of DD95 with amoxicillin, tetracycline, or metronidazole antibiotics on $\mathrm{H}$. pylori strains were also observed. Furthermore, DD95 can reduce the adhesion of $H$. pylori to human gastric cancer cells (TSGH 9201) as observed using fluorescence microscopy.

\section{Results and Discussion}

\subsection{Effects of DD95 Chitosan on Growth and Urease Production of H. pylori}

Based on the method described by Chang et al. [16], a chitosan with a MW of $220 \mathrm{kDa}$ and $95 \%$ degree of deacetylation (DD95) was chemically prepared from shrimp chitin. Five strains of H. pylori, including 3 standard strains (BCRC 15415, BCRC 10721, BCRC 10726) and 2 clinical isolates (No. 123, and 125) were used as the test strains. The antibacterial effects induced by DD95 against these test strains in serum added brain heart infusion broth (sBHIB) with various concentrations of DD95 in micro-aerobic culture conditions at $37^{\circ} \mathrm{C}$ for 1 day are shown in Figure $1 \mathrm{~A}$. A dose-dependent reduction of $H$. pylori counts induced by DD95 was observed. The survival counts ranging from 4.92 to $5.56 \mathrm{Log}$ $\mathrm{CFU} / \mathrm{mL}$ for the tested strains at $4000 \mu \mathrm{g} / \mathrm{mL}$ DD95 were obtained, which were significantly lower than those (7.20 to $7.57 \mathrm{Log} \mathrm{CFU} / \mathrm{mL}$ ) of the controls for each strain. All the 5 tested strains showed similar susceptibility to DD95.

(A)

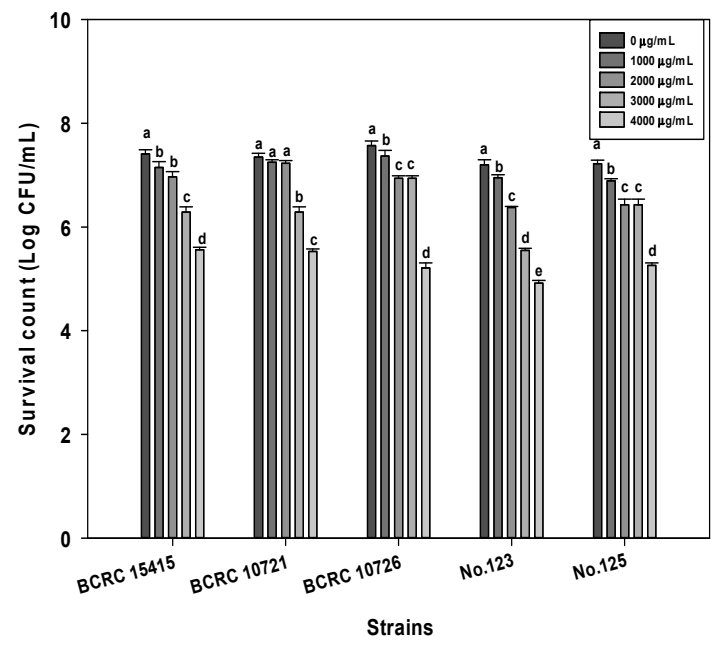

(B)

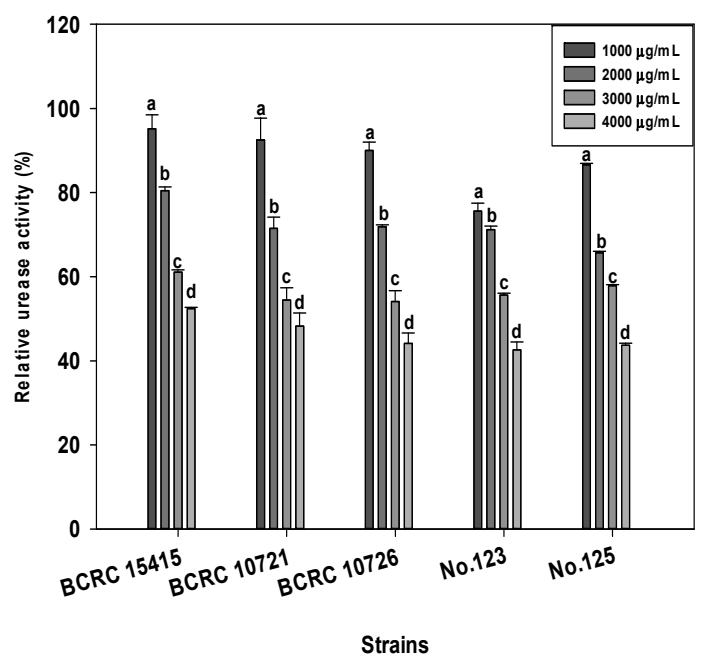

Figure 1. Survival counts, (A) and relative urease production of, (B) 5 strains of H. pylori in serum-added BHIB containing various concentrations of DD 95 at $37^{\circ} \mathrm{C}$ for $24 \mathrm{~h}$. a-e, Different letters in the bar for the same test item are significantly different $(p<0.05)$. 
Effects of DD95 on the relative urease activity of $H$. pylori at $37^{\circ} \mathrm{C}$ for $24 \mathrm{~h}$ are shown in Figure $1 \mathrm{~B}$. The relative urease activity of each strain tested significantly decreased with increasing concentrations of DD95. The relative urease activities ranged from $42.58 \%$ to $52.40 \%$ for the 5 tested strains at 4000 ppm DD95. The production of bacterial urease leads to the production of ammonia, which maintains the $\mathrm{pH}$ of the periplasm and cytoplasm of bacteria close to neutral even in the case of gastric acid shock, allowing the bacteria to survive and colonize the stomach mucosa [17].Therefore, a decrease in urease activity observed across $H$. pylori standard strains and clinical isolates in study is of therapeutic significance $[14,18]$.

The H. pylori strains BCRC 10726, No. 123, and 125 were chosen to further investigate the effects of $\mathrm{pH}$ on bacterial growth and urease production in SBHIB medium with or without 4000 DD95 chitosan. In the presence of $4000 \mu \mathrm{g} / \mathrm{mL}$ DD95, the bacterial survival count decreased with decreasing $\mathrm{pH}$ and the survival percentage ranged from $0.53 \%$ to $10.02 \%$ for the 3 tested strains at $\mathrm{pH} 2.0$ to 6.0 , when compared to the survivals of control strains. At $\mathrm{pH} 7$ and $\mathrm{pH} 8$, limited antibacterial effects by DD95 were observed and accordingly, much higher survival percentages ranging from $89.90 \%$ to $94.30 \%$ were achieved (Table 1 ). Furthermore, H. pylori cells are quite resistant to acidic conditions, thus the bacterial count of the control groups reduced only by 0.35 to $0.47 \mathrm{Log} \mathrm{CFU} / \mathrm{mL}$, compared to pH 7.0 and $\mathrm{pH} 3.0$ conditions.

In the absence of DD95, the highest urease activities as revealed by the absorbance at $550 \mathrm{~nm}$ $\left(\mathrm{OD}_{550}\right)$ in Table 2 for the 3 tested strains were obtained in $\mathrm{SBHIB}$ at $\mathrm{pH}$ 4.0. The increase or decrease of $\mathrm{pH}$ values from $\mathrm{pH} 4.0$ resulted in the changes in urease activity, and especially at $\mathrm{pH} 7$ and 8 , urease activity decreased significantly. In the presence of $4000 \mu \mathrm{g} / \mathrm{mL}$ DD95, the relative urease activity for the 3 tested strains increased with increasing $\mathrm{pH}$ of the sBHIB culture. In particular, at $\mathrm{pH} 7$ and 8 , limited inhibitory effects induced by DD95 were observed. The antibacterial activity of chitosan relies on its positive charge [16,19], thus a greater positive charge of the chitosan molecule was obtained in more acidic conditions. Accordingly, the inhibitory effects of DD95 on bacterial growth and urease production by $H$. pylori increased with decreasing $\mathrm{pH}$ values from $\mathrm{pH} 6.0$ to $\mathrm{pH} 2.0$. In addition, the larger molecular size of DD95 did not exert any antibacterial activity at pH values of 7.0 or above [16], likewise, limited inhibition on bacterial growth and urease production was observed.

It is known that chitosan has good antibacterial activity against many food pathogens and spoilage bacteria. For example, the minimal lethal concentration (MLC) of the chitosan with 95\% DD and $51 \mathrm{kDa}$ against the Gram negative bacteria of Escherichia coli, Pseudomonas. aeruginosa, Shigella. dysenteriae, Vibrio cholerae and V. parahaemolyticus, and Gram positive bacteria of Bacillus cereus, Listeria monocytogenes and Staphylococcus aureus were in the range of 50-200 $\mu \mathrm{g} / \mathrm{mL}$ [20]; while the MLC of the chitosan (95\% DD, $220 \mathrm{KDa}$ ) against Clostridium perfringens was $250 \mu \mathrm{g} / \mathrm{mL}$ [21]. In this study, the chitosan at $4000 \mu \mathrm{g} / \mathrm{mL}$, the concentration of which was much higher than the MLCs mentioned above, could not completely inhibit the growth of H. pylori. The antibacterial mechanism of chitosan is through binding the positively charged groups of chitosan with negatively charged groups on the bacterial surface due to electrostatic attraction, which in turn causes perforation or changes in cell membranes, and finally causes bacterial death [16]. The fact that H. pylori is much more resistant to chitosan, than the bacteria mentioned above, may be related to the differences in the surface structure between $H$. pylori and other bacteria. This merits further study in the future. 
Table 1. The survival (\%) ${ }^{1}$ of $H$. pylori BCRC10726, No.123, No.125 in serum-BHIB ${ }^{2}$ (pH 2.0-8.0) with/without chitosan (4000 $\mu \mathrm{g} / \mathrm{mL}$ ) and incubated micro-aerobically at $37^{\circ} \mathrm{C}$ for $6 \mathrm{~h}$.

\begin{tabular}{|c|c|c|c|c|c|c|c|c|c|}
\hline \multirow{3}{*}{$\mathrm{pH}$} & \multicolumn{3}{|c|}{ BCRC 10726} & \multicolumn{3}{|c|}{ No.123 } & \multicolumn{3}{|c|}{ No.125 } \\
\hline & \multicolumn{2}{|c|}{$\begin{array}{c}\text { Bacterial Count }^{2} \\
(\log \text { CFU } / \mathrm{mL})\end{array}$} & \multirow{2}{*}{$\begin{array}{c}\text { Survival } \\
(\%)\end{array}$} & \multicolumn{2}{|c|}{$\begin{array}{l}\text { Bacterial Count } \\
(\log \text { CFU/mL })\end{array}$} & \multirow{2}{*}{$\begin{array}{l}\text { Survival } \\
(\%)\end{array}$} & \multicolumn{2}{|c|}{$\begin{array}{l}\text { Bacterial Count } \\
(\log \text { CFU/mL) }\end{array}$} & \multirow{2}{*}{$\begin{array}{c}\text { Survival } \\
(\%)\end{array}$} \\
\hline & Control & Chitosan & & Control & Chitosan & & Control & Chitosan & \\
\hline 2 & $5.49 \pm 0.01^{\mathrm{D}}$ & $3.22 \pm 0.06$ & $0.53^{\mathrm{D}, 3}$ & $5.41 \pm 0.02^{\mathrm{D}}$ & $3.23 \pm 0.03$ & $0.65^{\mathrm{D}}$ & $5.20 \pm 0.03^{\mathrm{E}}$ & $3.27 \pm 0.03$ & $1.17^{\mathrm{D}}$ \\
\hline 3 & $6.62 \pm 0.01^{C}$ & $4.47 \pm 0.01$ & $0.70^{\mathrm{D}}$ & $6.66 \pm 0.05^{C}$ & $4.95 \pm 0.06$ & $1.94^{\mathrm{D}}$ & $6.59 \pm 0.02 \mathrm{D}$ & $4.99 \pm 0.05$ & $3.51^{\mathrm{D}}$ \\
\hline 4 & $6.83 \pm 0.03^{B}$ & $5.50 \pm 0.00$ & $4.71^{\mathrm{C}}$ & $6.85 \pm 0.05^{\mathrm{B}}$ & $5.36 \pm 0.05$ & $3.22^{\mathrm{D}}$ & $6.79 \pm 0.05^{C}$ & $5.44 \pm 0.03$ & $4.51^{\mathrm{D}}$ \\
\hline 7 & $6.97 \pm 0.01 \mathrm{~A}$ & $6.93 \pm 0.02$ & $89.90^{\mathrm{A}}$ & $7.06 \pm 0.06^{\mathrm{A}}$ & $7.02 \pm 0.06$ & $90.72^{\mathrm{B}}$ & $7.06 \pm 0.02 \mathrm{~A}$ & $7.02 \pm 0.04$ & $89.89^{\text {В }}$ \\
\hline 8 & $6.97 \pm 0.00^{\mathrm{A}}$ & $6.93 \pm 0.01$ & $91.63^{A}$ & $7.03 \pm 0.01^{A}$ & $7.02 \pm 0.01$ & $96.63^{\mathrm{A}}$ & $7.06 \pm 0.02^{\mathrm{A}}$ & $7.04 \pm 0.03$ & $94.30^{\mathrm{A}}$ \\
\hline
\end{tabular}

${ }^{1}$ Survival $(\%)=($ Count $(\mathrm{CFU} / \mathrm{mL})$ with chitosan/Count $(\mathrm{CFU} / \mathrm{mL})$ without chitosan $) \times 100 \% .{ }^{2}$ Values are mean \pm SD of determination on three individual experiments. ${ }^{3}$ Values in the same column with different capital letters $\left({ }^{\mathrm{A}-\mathrm{E}}\right)$ are significantly different $(p<0.05)$.

Table 2. The relative urease activity ${ }^{1}$ (\%) of H. pylori BCRC10726, No.123, No.125 in serum-BHIB (pH 2.0-8.0) with/without chitosan (4000 $\mu$ g/mL) and incubated micro-aerobically at $37^{\circ} \mathrm{C}$ for $6 \mathrm{~h}$.

\begin{tabular}{|c|c|c|c|c|c|c|c|c|c|}
\hline \multirow{3}{*}{$\mathrm{pH}$} & \multicolumn{3}{|c|}{ BCRC 10726} & \multicolumn{3}{|c|}{ No. 123} & \multicolumn{3}{|c|}{ No. 125} \\
\hline & \multicolumn{2}{|c|}{$\mathrm{OD}_{550}$} & \multirow{2}{*}{$\begin{array}{c}\text { Relative Urease } \\
\text { Activity (\%) }\end{array}$} & \multicolumn{2}{|c|}{$\mathrm{OD}_{550}$} & \multirow{2}{*}{$\begin{array}{c}\text { Relative Urease } \\
\text { Activity (\%) }\end{array}$} & \multicolumn{2}{|c|}{$\mathrm{OD}_{550}$} & \multirow{2}{*}{$\begin{array}{c}\text { Relative Urease } \\
\text { Activity (\%) }\end{array}$} \\
\hline & Control & Chitosan & & Control & Chitosan & & Control & Chitosan & \\
\hline 2 & $0.40 \pm 0.00^{C}$ & $0.15 \pm 0.00^{2}$ & $37.84 \pm 0.35^{\mathrm{D}, 3}$ & $0.39 \pm 0.01^{C}$ & $0.18 \pm 0.00$ & $45.58 \pm 1.52^{\mathrm{F}}$ & $0.41 \pm 0.00^{C}$ & $0.19 \pm 0.01$ & $46.58 \pm 0.37^{\mathrm{F}}$ \\
\hline 3 & $0.41 \pm 0.00^{C}$ & $0.18 \pm 0.01$ & $43.72 \pm 0.35^{\mathrm{C}}$ & $0.40 \pm 0.01^{C}$ & $0.19 \pm 0.01$ & $48.63 \pm 1.93^{\mathrm{E}}$ & $0.42 \pm 0.00^{C}$ & $0.22 \pm 0.00$ & $51.93 \pm 0.64^{\mathrm{E}}$ \\
\hline 4 & $0.44 \pm 0.01^{\mathrm{A}}$ & $0.21 \pm 0.00$ & $47.82 \pm 0.98^{B}$ & $0.44 \pm 0.01^{\mathrm{A}}$ & $0.22 \pm 0.00$ & $49.25 \pm 0.58^{\mathrm{D}, \mathrm{E}}$ & $0.45 \pm 0.00^{\mathrm{A}}$ & $0.25 \pm 0.01$ & $54.84 \pm 0.54^{\mathrm{D}}$ \\
\hline 5 & $0.42 \pm 0.00^{B}$ & $0.20 \pm 0.01$ & $48.61 \pm 1.08^{B}$ & $0.43 \pm 0.01^{\mathrm{A}, \mathrm{B}}$ & $0.22 \pm 0.00$ & $50.51 \pm 0.69 \mathrm{C}, \mathrm{D}$ & $0.44 \pm 0.00^{B}$ & $0.24 \pm 0.00$ & $56.02 \pm 0.41 \mathrm{C}, \mathrm{D}$ \\
\hline 6 & $0.41 \pm 0.00^{C}$ & $0.20 \pm 0.01$ & $49.51 \pm 0.25^{B}$ & $0.42 \pm 0.00^{\mathrm{B}}$ & $0.22 \pm 0.01$ & $51.34 \pm 0.51^{C}$ & $0.43 \pm 0.01^{\mathrm{B}}$ & $0.25 \pm 0.00$ & $47.39 \pm 1.09 \mathrm{C}$ \\
\hline 7 & $0.20 \pm 0.00^{\mathrm{D}}$ & $0.20 \pm 0.00$ & $97.54 \pm 0.50 \mathrm{~A}$ & $0.21 \pm 0.01^{\mathrm{D}}$ & $0.20 \pm 0.01$ & $93.45 \pm 1.06^{B}$ & $0.21 \pm 0.01 \mathrm{D}$ & $0.20 \pm 0.01$ & $94.85 \pm 0.61^{\mathrm{B}}$ \\
\hline 8 & $0.20 \pm 0.01^{\mathrm{D}}$ & $0.20 \pm 0.01$ & $97.35 \pm 0.71 \mathrm{~A}$ & $0.21 \pm 0.01^{\mathrm{D}}$ & $0.20 \pm 0.01$ & $97.89 \pm 0.24 \mathrm{~A}$ & $0.21 \pm 0.01 \mathrm{D}$ & $0.20 \pm 0.01$ & $97.89 \pm 0.63^{\mathrm{A}}$ \\
\hline
\end{tabular}

${ }^{1}$ Relative urease activity $(\%)=\left(\mathrm{OD}_{550}\right.$ of Sample $/ \mathrm{OD}_{550}$ of Control $) \times 100 \% .{ }^{2}$ Values are mean $\pm \mathrm{SD}$ of determination on three individual experiments. ${ }^{3}$ Values in the same column with different capital letters $\left({ }^{\mathrm{A}-\mathrm{F}}\right)$ are significantly different $(p<0.05)$. 


\subsection{Combination of DD95 Chitosan and Antibiotics against H. pylori}

Pathogenic microorganisms (including $H$. pylori) have developed drug resistance, thus antimicrobial chemotherapy often fails to achieve the expected success in eradicating microbial infections. Histological studies have shown that gastritis can be cured by eradicating H. pylori from the gastric mucosa [1]. The eradication of this pathogen not only heals ulcers, but also reduces the recurrence rate and is fundamentally curative for peptic ulcers [22]. Although, triple therapy, including amoxicillin plus other antibiotics is currently used, this strategy is complicated, has obvious side effects and compliance issues, and often leads to relapse [23]. Therefore, the impact of amoxicillin, tetracycline, and metronidazole plus $4000 \mu \mathrm{g} / \mathrm{mL}$ DD95 against $H$. pylori were evaluated in sBHIB at pH 6.0 and $\mathrm{pH} 2.0$, as shown in Tables 3 and 4, respectively.

As shown in Table 3, the survival counts for the 3 strains tested in sBHIB ( $\mathrm{pH}$ 6.0) containing $4000 \mu \mathrm{g} / \mathrm{mL}$ DD95 ranged from 5.13 to $5.39 \mathrm{Log}$ CFU/mL, which was about a 2 Log reduction compared to the survival of the control strains (7.20 to $7.61 \mathrm{Log} C F U / \mathrm{mL})$. The three individual antibiotics tested showed much higher antibacterial activity against $H$. pylori than treatment with DD95 chitosans alone. The survival counts of three $H$. pylori strains at $50 \mu \mathrm{g} / \mathrm{mL}$ of amoxicillin, tetracycline, and metronidazole ranged 4.36 to $4.56 \mathrm{Log}$ CFU/mL, 5.37 to $5.69 \mathrm{Log} \mathrm{CFU} / \mathrm{mL}$, and 4.69 to $5.11 \mathrm{Log}$ $\mathrm{CFU} / \mathrm{mL}$, respectively. The survival counts gradually decreased with increasing concentrations (50 to $200 \mu \mathrm{g} / \mathrm{mL}$ ) of antibiotics, with survival ranging from 2.25 to $4.28 \mathrm{Log}$ CFU/mL at a concentration of $200 \mu \mathrm{g} / \mathrm{mL}$ of antibiotics. No bacterial counts were observed at $4000 \mu \mathrm{g} / \mathrm{mL}$ of tested antibiotics. Combination effects of antibiotics with $4000 \mu \mathrm{g} / \mathrm{mL}$ DD95 chitosan were observed. No survival was observed at a concentration of $50 \mu \mathrm{g} / \mathrm{mL}$ amoxicillin plus $4000 \mu \mathrm{g} / \mathrm{mL}$ DD95 chitosan or for the combination of $100 \mu \mathrm{g} / \mathrm{mL}$ tetracycline/metronidazole plus $4000 \mu \mathrm{g} / \mathrm{mL}$ DD95 chitosan. Overall, H. pylori counts in the presence of $50 \mu \mathrm{g} / \mathrm{mL}$ antibiotics of 3 tested antibiotics at $\mathrm{pH} 6.0$ were decreased by 1.51-3.19 Log CFU/mL; while H. pylori counts were strongly decreased by 3.67-7.61 Log CFU/mL by adding $4000 \mu \mathrm{g} / \mathrm{mL}$ DD95 into the $50 \mu \mathrm{g} / \mathrm{mL}$ antibiotic-containing culture medium.

Table 3. Effect of various concentrations of antibiotics with/without chitosan against of $H$. pylori BCRC 10726, No. 123 , No. 125 at $\mathrm{pH} 6.0$ for $6 \mathrm{~h}$.

\begin{tabular}{|c|c|c|c|c|c|c|c|}
\hline \multirow{4}{*}{$\begin{array}{r}\text { Antibioti } \\
(\mu \mathrm{g} / \mathrm{mL})\end{array}$} & & \multicolumn{2}{|c|}{ BCRC 10726} & \multicolumn{2}{|c|}{ No. 123} & \multicolumn{2}{|c|}{ No. 125} \\
\hline & & \multicolumn{2}{|c|}{$\begin{array}{l}\text { Bacterial Count } \\
\text { (Log CFU/mL) }\end{array}$} & \multicolumn{2}{|c|}{$\begin{array}{l}\text { Bacterial Count } \\
\text { (Log CFU/mL) }\end{array}$} & \multicolumn{2}{|c|}{$\begin{array}{l}\text { Bacterial Count } \\
\text { (Log CFU/mL) }\end{array}$} \\
\hline & & \multicolumn{2}{|c|}{ Chitosan conc. $(\mu \mathrm{g} / \mathrm{mL})$} & \multicolumn{2}{|c|}{ Chitosan conc. $(\mu \mathrm{g} / \mathrm{mL})$} & \multicolumn{2}{|c|}{ Chitosan conc. $(\mu \mathrm{g} / \mathrm{mL})$} \\
\hline & & 0 & 4000 & $\mathbf{0}$ & 4000 & 0 & 4000 \\
\hline Control & & $7.20 \pm 0.03^{1}$ & $5.32 \pm 0.10$ & $7.61 \pm 0.02$ & $5.13 \pm 0.05$ & $7.59 \pm 0.01$ & $5.39 \pm 0.07$ \\
\hline \multirow{4}{*}{ Amoxicillin } & 50 & $4.36 \pm 0.01$ & $0.00 \pm 0.00$ & $4.42 \pm 0.01$ & $0.00 \pm 0.00$ & $4.56 \pm 0.01$ & $0.00 \pm 0.00$ \\
\hline & 100 & $3.26 \pm 0.01$ & $0.00 \pm 0.00$ & $4.31 \pm 0.01$ & $0.00 \pm 0.00$ & $4.33 \pm 0.01$ & $0.00 \pm 0.00$ \\
\hline & 200 & $2.25 \pm 0.05$ & $0.00 \pm 0.00$ & $3.74 \pm 0.04$ & $0.00 \pm 0.00$ & $4.04 \pm 0.02$ & $0.00 \pm 0.00$ \\
\hline & 4000 & $0.00 \pm 0.00$ & - & $0.00 \pm 0.00$ & - & $0.00 \pm 0.00$ & - \\
\hline \multirow{4}{*}{ Tetracycline } & 50 & $5.69 \pm 0.02$ & $3.24 \pm 0.02$ & $5.37 \pm 0.05$ & $3.84 \pm 0.03$ & $5.39 \pm 0.01$ & $3.92 \pm 0.02$ \\
\hline & 100 & $5.02 \pm 0.03$ & $0.00 \pm 0.00$ & $4.75 \pm 0.01$ & $0.00 \pm 0.00$ & $4.78 \pm 0.01$ & $0.00 \pm 0.00$ \\
\hline & 200 & $3.98 \pm 0.02$ & $0.00 \pm 0.00$ & $2.80 \pm 0.04$ & $0.00 \pm 0.00$ & $3.22 \pm 0.01$ & $0.00 \pm 0.00$ \\
\hline & 4000 & $0.00 \pm 0.00$ & - & $0.00 \pm 0.00$ & - & $0.00 \pm 0.00$ & - \\
\hline \multirow{4}{*}{ Metronidazole } & 50 & $4.69 \pm 0.01$ & $2.46 \pm 0.02$ & $5.07 \pm 0.01$ & $3.38 \pm 0.02$ & $5.11 \pm 0.02$ & $3.64 \pm 0.02$ \\
\hline & 100 & $4.55 \pm 0.02$ & $0.00 \pm 0.00$ & $3.89 \pm 0.00$ & $0.00 \pm 0.00$ & $3.95 \pm 0.00$ & $0.00 \pm 0.00$ \\
\hline & 200 & $4.28 \pm 0.02$ & $0.00 \pm 0.00$ & $3.10 \pm 0.02$ & $0.00 \pm 0.00$ & $3.34 \pm 0.02$ & $0.00 \pm 0.00$ \\
\hline & 4000 & $0.00 \pm 0.00$ & - & $0.00 \pm 0.00$ & - & $0.00 \pm 0.00$ & - \\
\hline
\end{tabular}

\footnotetext{
${ }^{1}$ Values are mean \pm SD of determination on three individual experiments. -: Not detected.
} 
Table 4. Effect of various concentrations of antibiotics with/without chitosan against of $H$. pylori BCRC 10726, No. 123, No. 125 at pH 2.0 for 6 h.

\begin{tabular}{|c|c|c|c|c|c|c|c|}
\hline \multirow{4}{*}{$\begin{array}{c}\text { Antibiotic } \\
(\mu \mathrm{g} / \mathrm{mL})\end{array}$} & & \multicolumn{2}{|c|}{ BCRC 10726} & \multicolumn{2}{|c|}{ No. 123} & \multicolumn{2}{|c|}{ No. 125} \\
\hline & & \multicolumn{2}{|c|}{$\begin{array}{l}\text { Bacterial Count } \\
\text { (Log CFU/mL) }\end{array}$} & \multicolumn{2}{|c|}{$\begin{array}{l}\text { Bacterial Count } \\
\text { (Log CFU/mL) }\end{array}$} & \multicolumn{2}{|c|}{$\begin{array}{l}\text { Bacterial Count } \\
\text { (Log CFU/mL) }\end{array}$} \\
\hline & & \multicolumn{2}{|c|}{ Chitosan $(\mu \mathrm{g} / \mathrm{mL})$} & \multicolumn{2}{|c|}{ Chitosan $(\mu \mathrm{g} / \mathrm{mL})$} & \multicolumn{2}{|c|}{ Chitosan $(\mu \mathrm{g} / \mathrm{mL})$} \\
\hline & & 0 & 4000 & 0 & 4000 & 0 & 4000 \\
\hline Control & & $6.70 \pm 0.03^{1}$ & $3.97 \pm 0.06$ & $6.61 \pm 0.02$ & $4.28 \pm 0.02$ & $6.66 \pm 0.04$ & $4.52 \pm 0.01$ \\
\hline \multirow{4}{*}{ Amoxicillin } & 50 & $4.08 \pm 0.03$ & $0.00 \pm 0.00$ & $3.83 \pm 0.01$ & $0.00 \pm 0.00$ & $3.84 \pm 0.00$ & $0.00 \pm 0.00$ \\
\hline & 100 & $3.44 \pm 0.02$ & $0.00 \pm 0.00$ & $3.60 \pm 0.01$ & $0.00 \pm 0.00$ & $3.63 \pm 0.01$ & $0.00 \pm 0.00$ \\
\hline & 200 & $3.08 \pm 0.03$ & $0.00 \pm 0.00$ & $3.30 \pm 0.01$ & $0.00 \pm 0.00$ & $3.40 \pm 0.00$ & $0.00 \pm 0.00$ \\
\hline & 4000 & $0.00 \pm 0.00$ & - & $0.00 \pm 0.00$ & - & $0.00 \pm 0.00$ & - \\
\hline \multirow{4}{*}{ Tetracycline } & 50 & $5.23 \pm 0.03$ & $0.00 \pm 0.00$ & $4.39 \pm 0.02$ & $0.00 \pm 0.00$ & $4.18 \pm 0.02$ & $0.00 \pm 0.00$ \\
\hline & 100 & $4.58 \pm 0.01$ & $0.00 \pm 0.00$ & $3.75 \pm 0.01$ & $0.00 \pm 0.00$ & $3.02 \pm 0.02$ & $0.00 \pm 0.00$ \\
\hline & 200 & $3.39 \pm 0.01$ & $0.00 \pm 0.00$ & $1.79 \pm 0.01$ & $0.00 \pm 0.00$ & $2.47 \pm 0.02$ & $0.00 \pm 0.00$ \\
\hline & 4000 & $0.00 \pm 0.00$ & - & $0.00 \pm 0.00$ & - & $0.00 \pm 0.00$ & - \\
\hline \multirow{4}{*}{ Metronidazole } & 50 & $4.23 \pm 0.00$ & $0.00 \pm 0.00$ & $4.08 \pm 0.01$ & $0.00 \pm 0.00$ & $4.46 \pm 0.00$ & $0.00 \pm 0.00$ \\
\hline & 100 & $4.10 \pm 0.05$ & $0.00 \pm 0.00$ & $2.91 \pm 0.00$ & $0.00 \pm 0.00$ & $3.87 \pm 0.03$ & $0.00 \pm 0.00$ \\
\hline & 200 & $3.84 \pm 0.02$ & $0.00 \pm 0.00$ & $2.10 \pm 0.02$ & $0.00 \pm 0.00$ & $2.49 \pm 0.02$ & $0.00 \pm 0.00$ \\
\hline & 4000 & $0.00 \pm 0.00$ & - & $0.00 \pm 0.00$ & - & $0.00 \pm 0.00$ & - \\
\hline
\end{tabular}

${ }^{1}$ Values are mean \pm SD of determination on three individual experiments. -: Not detected.

As most antibiotics tend to be directed at tissues having a relatively neutral $\mathrm{pH}$, some antibiotics may be unstable under acidic conditions. For example, amoxicillin may be degraded in simulated gastric fluid after three hours [24] and oral antibiotics for H. pylori infection may reduce the eradication rate in gastric juice having an acidic $\mathrm{pH}$ of 2.0. Indeed, in our study, the bacterial counts of $H$. pylori control strains cultured at $\mathrm{pH} 2.0$ were lower (range 6.61 to $6.70 \mathrm{Log} \mathrm{CFU} / \mathrm{mL}$ ) (Table 4) than those cultured at pH 6.0 (range 7.20 to 7.59 Log CFU/mL) (Table 2). Lower survivals (range 3.97 to 4.52 Log $\mathrm{CFU} / \mathrm{mL}$ ) for $4000 \mu \mathrm{g} / \mathrm{mL}$ of DD95 chitosan at $\mathrm{pH} 2.0$ than those at $\mathrm{pH} 6.0$ (range 5.13 to $5.39 \mathrm{Log}$ $\mathrm{CFU} / \mathrm{mL}$ ) (Table 3) were observed. The survival counts of three H. pylori strains cultured with $50 \mu \mathrm{g} / \mathrm{mL}$ of amoxicillin, tetracycline, and metronidazole at $\mathrm{pH} 2.0$ ranged 3.83 to $4.08 \mathrm{Log} \mathrm{CFU} / \mathrm{mL}, 4.18$ to $5.23 \mathrm{Log} \mathrm{CFU} / \mathrm{mL}$, and 4.08 to $4.46 \mathrm{Log} \mathrm{CFU} / \mathrm{mL}$, respectively. Accordingly, H. pylori count was decreased by 1.47-2.82 Log CFU/mL in the $50 \mu \mathrm{g} / \mathrm{mL}$ antibiotics-added medium (pH 2.0), compared to those of control. Counts of $H$. pylori were greatly reduced by adding DD95 into antibiotic supplementary medium at $\mathrm{pH}$ 2.0. No bacterial counts were found in the combination of antibiotic and $4000 \mu \mathrm{g} / \mathrm{mL}$ DD95, irrespective of the antibiotic concentrations tested. H. pylori counts were strongly decreased by 6.61-6.70 Log CFU/mL at $4000 \mu \mathrm{g} / \mathrm{mL}$ DD95 plus $50 \mu \mathrm{g} / \mathrm{mL}$ antibiotics at $\mathrm{pH}$ 2.0. Thus, our results show that DD95 chitosan enhances the antibiotic drug activity against $H$. pylori strains.

Given the high bacterial load observed with H. pylori infection [25] and the gastric niche [26] where H. pylori could be protected from both antibiotic activity and an immune response, drug concentrations need to remain elevated for prolonged periods in the stomach, in order to achieve their therapeutic effectiveness [27]. The combination of antibiotics and DD95 chitosan may greatly reduce the dosage of antibiotics required for successful treatment of $H$. pylori infection. This approach is particularly useful for the treatment of drug resistant strains.

\subsection{Adhesion of H. pylori to Human Gastric Carcinoma Cells (TSGH9201) in the Presence of DD95 Chitosan}

The effects of $200 \mu \mathrm{g} / \mathrm{mL}$ DD95 on the adhesion of the FITC-labeled H. pylori BCRC17026 to human gastric carcinoma cells are shown in Figure 2. For the control strains (not exposed to DD95), the FITC-labeled bacteria adhered to TSGH9201 cells and could be observed under both light (Figure 2A) and fluorescent microscopy (Figure 2C). The adhesion effects of bacteria were significantly reduced in the presence of DD95 treatment as observed using either light microscopy (Figure 2B) or fluorescent 
microscopy (Figure 2D). Explanations for the DD95-induced reduction in adhesion of $H$. pylori to TSGH9201 cells may include the reaction of DD95 with bacteria, which may retard bacterial binding with cells, or DD95 may react with cell surface residues, which prevent bacterial binding onto the cell surface. These potential activities merit further investigation to clarify the actual mechanism involved in DD95 interference with the adhesion of H. pylori to TSGH9201 cells.

(A)

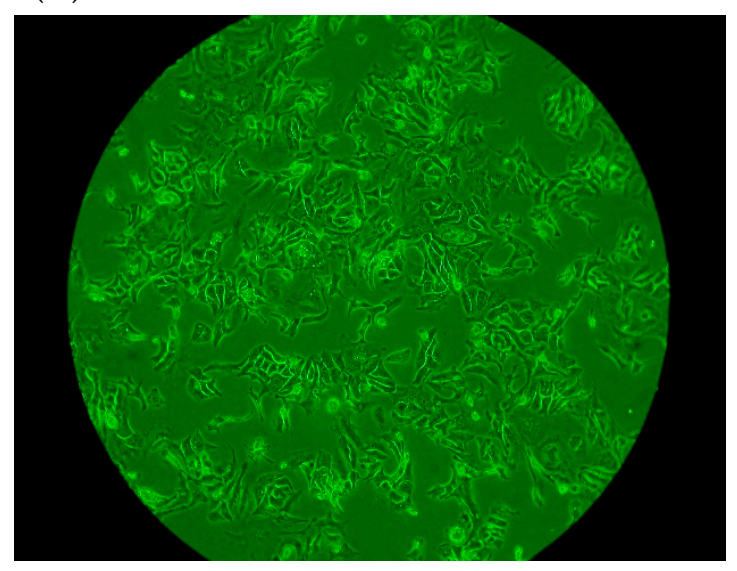

(B)

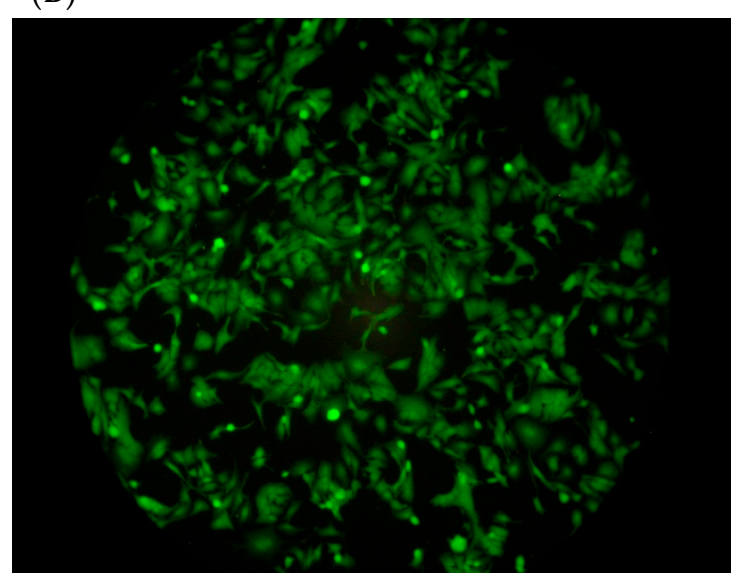

(C)

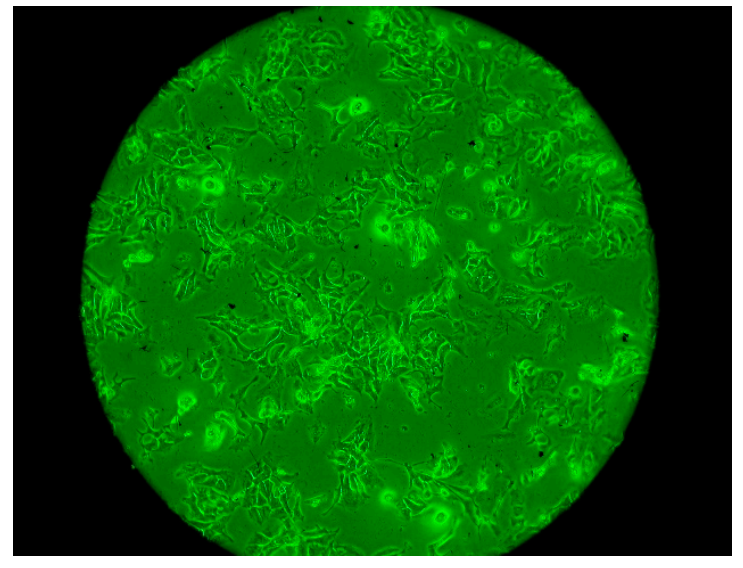

(D)

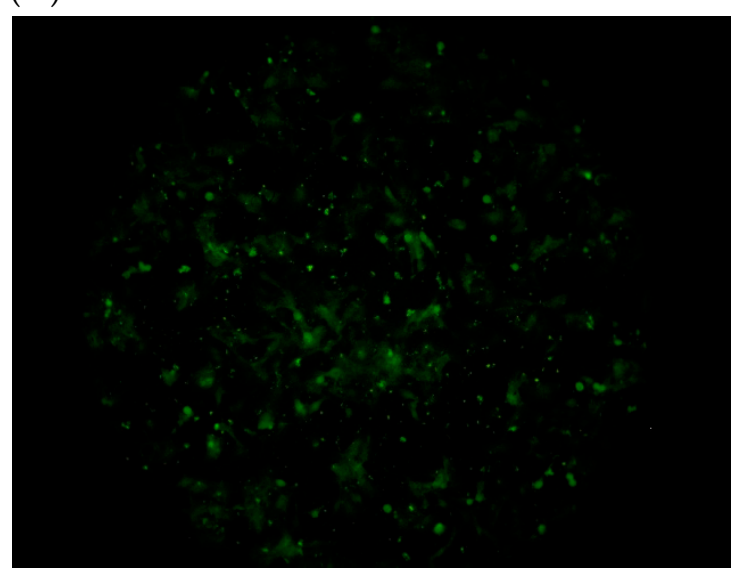

Figure 2. Effect of chitosan on the adhesion of H. pylori BCRC 17026 to TSGH cell line. (A) control, bright-field microscopic observation; (B) control, fluorescent microscopic observation; (C) chitosan $(200 \mu \mathrm{g} / \mathrm{mL})$ treatment, bright-field microscopic observation; (D) chitosan $(200 \mu \mathrm{g} / \mathrm{mL})$ treatment, fluorescent microscopic observation.

Antibiotic therapy of $H$. pylori destroyed the microenvironment in the stomach leading to side effects and the rapid spread of resistant $H$. pylori strains [28]. Considering the long history chitosan use in a variety of food applications all over the world and the proposal that DD95 could represent a potential significant alternative antibacterial agent, this study using chitosan supporting its antagonistic activity toward H. pylori may lay the foundation for food applications able to contribute to the prevention of gastric diseases caused by $H$. pylori or as adjuvant therapy against $H$. pylori infections.

\section{Material and Methods}

\subsection{Bacterial Strains, Cell Line, and Chemicals}

H. pylori BCRC 15415, BCRC 10721, BCRC 10726, and TSGH 9201(human gastric carcinoma) were purchased from the Bioresources Collection and Research Center (Hsinchu, Taiwan). H. pylori No. 123, and 125 were obtained from Professor M.S.Wu, Division of Gastroenterology, National Taiwan University Hospital, Taipei, Taiwan. Acetic acid, acetonitrile, dimethyl sulfoxide (DMSO), 
glycerol, methanol, and sodium hydroxide $(\mathrm{NaOH})$ were purchased from Fluka (Garage Gmbh, Buchs, Switzerland). Meanwhile, phenol red, amoxicillin, tetracycline, metronidazole, and sodium bicarbonate $\left(\mathrm{NaHCO}_{3}\right)$ were purchased from Sigma Chemical Co. (Gillingham, UK). Chitin powder was obtained from Applied Chemical Co., Ltd. (Kaohsiung, Taiwan). Brain heart infusion broth (BHIB), tryptic soy broth (TSB), tryptic soy agar (TSA), bacto agar, urea broth and 50\% egg yolk saline were supplied by Becton Dickinson (Sparks, MD, USA). RPMI-1640 medium and trypsin-EDTA were purchased from Gibco (New York, NY, USA)

\subsection{DD95 Chitosan Preparation}

Based on the method described by Chang, Lin, Wu and Tsai [16], a chitosan with 95.0\% deacetylation degree, as measured using the colloid titration method [29], was obtained after deacetylation of a shrimp chitin powder suspension in $50 \% \mathrm{NaOH}(1.0 \mathrm{~g}$ chitin per $13 \mathrm{~mL} \mathrm{NaOH})$ at $140{ }^{\circ} \mathrm{C}$ for $1 \mathrm{~h}$.

\subsection{Culture Conditions}

H. pylori tested strains were stored in SBHIB (Brain heart infusion broth (BHIB) added with $10 \%$ horse serum) containing $50 \%$ sterile glycerol at $-80{ }^{\circ} \mathrm{C}$. To prepare the bacteria cultures, the strains stored at $-80^{\circ} \mathrm{C}$ were inoculated into sTSA (Tryptic soy agar (TSA) containing $5 \%$ horse serum) slant and incubated micro-aerobically $\left(5 \% \mathrm{O}_{2}, 10 \% \mathrm{CO}_{2}\right.$, and $\left.85 \% \mathrm{~N}_{2}\right)$ by using anaerobic chamber with the micro-gas production pack (BBL Campypak 271034) at $37^{\circ} \mathrm{C}$ for $72 \mathrm{~h}$. All strains were sub-cultured twice in sBHIB and incubated micro-aerobically at $37^{\circ} \mathrm{C}$ for $72 \mathrm{~h}$. Finally, the cultures were diluted to $1.0 \times 10^{8} \mathrm{CFU} / \mathrm{mL}$ with sterile $0.1 \%$ peptone water before use.

\subsection{Antibacterial Test}

The $1 \%$ chitosan stock solution was prepared by adding $0.2 \mathrm{~g}$ of DD95 to $10 \mathrm{~mL}$ distilled water, sterilizing at $121^{\circ} \mathrm{C}$ for $15 \mathrm{~min}$, and then adding $10 \mathrm{~mL}$ sterile $0.2 \mathrm{~N} \mathrm{HCl}$. In $50 \mathrm{~mL}$-volume flasks containing $10 \mathrm{~mL}$ sBHIB, the 1\% DD95 stock solution was added to obtain 1000, 2000, 3000, and 4000 $\mu \mathrm{g} / \mathrm{mL}$. Next, $1 \mathrm{~mL}$ of $H$. pylori culture were added to have an initial density of ca. $10^{6} \mathrm{CFU} / \mathrm{mL}$, and incubated micro-aerobically at $37^{\circ} \mathrm{C}$ for $6 \mathrm{~h}$. Then, $0.1 \mathrm{~mL}$ aliquots of decimal dilutions of each culture were spread onto sTSA agar plates, and incubated micro-aerobically at $37^{\circ} \mathrm{C}$ for $72 \mathrm{~h}$ before the colonies were counted. The experiments were run in triplicate.

In another trial, the medium of sBHIB plus $4000 \mu \mathrm{g} / \mathrm{mL}$ was adjusted to $\mathrm{pH}$ 2.0, 3.0, 4.0, 5.0, 6.0, 7.0, and 8.0, respectively, using $0.1 \mathrm{~N} \mathrm{HCl}$ and $\mathrm{NaOH}$, before the $H$. pylori culture were added as described above to investigate the $\mathrm{pH}$ effects on the antibacterial activity of DD95.

\subsection{Combination Effects of Antibiotic and DD95 Chitosan against H. pylori}

The medium of sBHIB with/without $4000 \mu \mathrm{g} / \mathrm{mL}$ DD 95 with $\mathrm{pH}$ value of $\mathrm{pH} 2.0$ and $\mathrm{pH} 6.0$ was added with the antibiotics of amoxicillin, tetracycline, and metronidazole to obtain the concentrations of 50,100, 200, and $4000 \mu \mathrm{g} / \mathrm{mL}$, respectively. Then, $1 \mathrm{~mL}$ of $H$. pylori culture were added to have an initial density of ca. $10^{7} \mathrm{CFU} / \mathrm{mL}$, and incubated micro-aerobically at $37^{\circ} \mathrm{C}$ for $6 \mathrm{~h}$. The survival count was measured by spreading each sample on sTSA agar plates and incubated micro-aerobically at $37^{\circ} \mathrm{C}$ for $72 \mathrm{~h}$.

\subsection{Urease Activity Assay}

After treatment of $H$. pylori culture in SBHIB with/without DD 95 chitosan plus various amounts of antibiotics at $37^{\circ} \mathrm{C}$ for $6 \mathrm{~h}$, the urease production activity by $\mathrm{H}$. pylori was evaluated, based on the method described by Adeniyi and Anyiam [18]. Briefly, the incubated P. pylori cultures were centrifuged $\left(8800 \times g, 10 \mathrm{~min}, 4^{\circ} \mathrm{C}\right)$. The collected sediments were washed twice with $0.02 \mathrm{M}$ phosphate buffer solution (PBS, pH 6.8) and re-suspended in the same PBS (pH 6.8) for the urease activity assay. One milliter of the bacterial suspension was added to sterile test tube containing $0.03 \mathrm{M}$ 
PBS (pH 6.8), $50 \mu \mathrm{L}$ of $0.4 \%$ phenol red and $2 \%$ urea, mixed thoroughly and incubated at $37^{\circ} \mathrm{C}$ for $30 \mathrm{~min}$. The absorbance at $550 \mathrm{~nm}\left(\mathrm{~A}_{550}\right)$ was measured using a colorimeter (UV-160-A, Shimadzu, Tokyo, Japan):

Relative urease activity $(\%)=\left(\mathrm{A}_{550}\right.$ of Sample $/ \mathrm{A}_{550}$ of Control $) \times 100 \%$.

\subsection{Adherence of Fluorescein-Labeled H. pylori to Human Gastric Carcinoma Cells in the Presence of DD95 Chitosan}

Human gastric carcinoma TSGH 9201 cells were cultured in RPMI1640 supplemented with 10\% fetal calf serum (FCS) at $37^{\circ} \mathrm{C}$ in an atmosphere of $5 \% \mathrm{CO}_{2}$. Cells were sub-cultured every 2 days with the addition of fresh medium according to standard procedures. Based on the method of Tsai, et al. [30], TSGH 9201 cells $\left(1 \times 10^{5}\right.$ cells $\left./ \mathrm{mL}\right)$ on the well were added with $0.25 \%$ glutaraldehyde to prepare glutaraldehyde-fixed TSGH 9201 cells. Then, H. pylori cells collected from the sBHIB cultures were washed twice with PBS ( $\mathrm{pH}$ 6.8) and re-suspended in 0.03M PBS ( $\mathrm{pH}$ 6.8) to have a cell density of $10^{6}$ $\mathrm{CFU} / \mathrm{mL}$. This cell suspension was then mixed with equal volumes of fluorescein isothiocyanate (FITC) $(2 \mathrm{mg} / \mathrm{mL})$ at $20^{\circ} \mathrm{C}$ for $30 \mathrm{~min}$. After centrifugation (Himac CR-21, HITACHI, Tokyo, Japan) $(8000 \times g$, $20 \mathrm{~min}$ ), bacteria were washed three times with PBS until no FITC residue in the supernatant. The FITC labeled H. pylori cells $\left(1 \times 10^{6}\right.$ per well $)$ with $200 \mu \mathrm{g} / \mathrm{mL}$ DD95 chitosan and without chitosan as control were added to glutaraldehyde-fixed TSGH 9201 cells, and cell plates were incubated at $37^{\circ} \mathrm{C}$ with $5 \%$ $\mathrm{CO}_{2}$ for $1.5 \mathrm{~h}$. After being washed three times with PBS, the cover slides were transferred to glass slides for a fluorescence microscopic observation.

\subsection{Statistical Analysis}

The data were analyzed using the general linear model (GLM) of Statistical Analysis System's Procedures (Version 9.3, SAS Institute Inc., Cary, NC, USA) with a 5\% level of significance. The means were separated using Duncan's new multiple range test.

\section{Conclusions}

In this study, DD95 chitosan in medium clearly inhibited the growth and urease production by $\mathrm{H}$. pylori and this inhibition effect was dose-dependent and $\mathrm{pH}$ dependent. The joint inhibitory effect of DD95 and the antibiotics of amoxicillin, tetracycline, and metronidazole on the growth and urease production of $H$. pylori strains were observed. This combination may represent a useful strategy in reducing the side effects observed with antibiotics therapy and shows strong potential as an alternative natural antibacterial agent. Moreover, DD95 chitosan significantly reduced the adherence of H. pylori onto human gastric carcinoma cells (TSGH 9201) indicating as a useful prevention agent from $H$. pylori infection.

Author Contributions: S.-H.C. performed the experiments and wrote the initial version of the manuscript; P.-L.H. designed the experiments and analyzed the data; G.-J.T. conceived the experiments, formally analyzed the data, and wrote, reviewed, and edited the paper. All authors have read and agreed to the published version of the manuscript.

Funding: This study was supported by the Ministry of Science and Technology, Taiwan: MOST 108-2321-B-019-001.

Conflicts of Interest: The authors declare no conflict of interest.

\section{References}

1. Moss, S.F. The clinical evidence linking Helicobacter pylori to gastric cancer. Cell. Mol. Gastroenterol. Hepatol. 2017, 3, 183-191. [CrossRef] [PubMed]

2. Zamani, M.; Ebrahimtabar, F.; Zamani, V.; Miller, W.; Alizadeh-Navaei, R.; Shokri-Shirvani, J.; Derakhshan, M. Systematic review with meta-analysis: The worldwide prevalence of Helicobacter pylori infection. Aliment. Pharmacol. Ther. 2018, 47, 868-876. [CrossRef] [PubMed] 
3. Thung, I.; Aramin, H.; Vavinskaya, V.; Gupta, S.; Park, J.; Crowe, S.; Valasek, M. the global emergence of Helicobacter pylori antibiotic resistance. Aliment. Pharmacol. Ther. 2016, 43, 514-533. [CrossRef] [PubMed]

4. Papastergiou, V.; Georgopoulos, S.D.; Karatapanis, S. Treatment of Helicobacter pylori infection: Meeting the challenge of antimicrobial resistance. World J. Gastroenterol. WJG 2014, 20, 9898. [CrossRef]

5. Harb, A.H.; El Reda, Z.D.; Sarkis, F.S.; Chaar, H.F.; Sharara, A.I. Efficacy of Reduced-Dose Regimen of a Capsule Containing Bismuth Subcitrate, Metronidazole, and Tetracycline Given with Amoxicillin and Esomeprazole in the Treatment of Helicobacter Pylori Infection; SAGE Publications Sage UK: London, UK, 2015.

6. Perri, F.; Festa, V.; Merla, A.; Quitadamo, M.; Clemente, R.; Andriulli, A. Amoxicillin-Tetracycline Combinations are Inadequate as Alternative Therapies for Helicobacter pylori Infection. Helicobacter 2002, 7, 99-104. [CrossRef]

7. Huang, Y.-Q.; Huang, G.-R.; Wu, M.-H.; Tang, H.-Y.; Huang, Z.-S.; Zhou, X.-H.; Yu, W.-Q.; Su, J.-W.; Mo, X.-Q.; Chen, B.-P. Inhibitory effects of emodin, baicalin, schizandrin and berberine on hefA gene: Treatment of Helicobacter pylori-induced multidrug resistance. World J. Gastroenterol. WJG 2015, 21, 4225. [CrossRef]

8. Cardoso, O.; Donato, M.M.; Luxo, C.; Almeida, N.; Liberal, J.; Figueirinha, A.; Batista, M.T. Anti-Helicobacter pylori potential of Agrimonia eupatoria L. and Fragaria vesca. J. Funct. Foods 2018, 44, 299-303. [CrossRef]

9. Sharifi, A.; Azizi, M.; Moradi-Choghakabodi, P.; Aghaei, S.; Azizi, A. In vitro anti-Helicobacter pylori activity of aqueous extract from Persian Oak testa. Chin. Herb. Med. 2019, 11, 394-399. [CrossRef]

10. Spósito, L.; Oda, F.B.; Vieira, J.H.; Carvalho, F.A.; dos Santos Ramos, M.A.; de Castro, R.C.; Crevelin, E.J.; Crotti, A.E.M.; Santos, A.G.; da Silva, P.B. In vitro and in vivo anti-Helicobacter pylori activity of Casearia sylvestris leaf derivatives. J. Ethnopharmacol. 2019, 233, 1-12. [CrossRef]

11. Mendes, J.; Paschoalin, R.; Carmona, V.; Neto, A.R.S.; Marques, A.; Marconcini, J.; Mattoso, L.; Medeiros, E.; Oliveira, J. Biodegradable polymer blends based on corn starch and thermoplastic chitosan processed by extrusion. Carbohydr. Polym. 2016, 137, 452-458. [CrossRef]

12. Notario-Pérez, F.; Martín-Illana, A.; Cazorla-Luna, R.; Ruiz-Caro, R.; Bedoya, L.-M.; Tamayo, A.; Rubio, J.; Veiga, M.-D. Influence of chitosan swelling behaviour on controlled release of tenofovir from mucoadhesive vaginal systems for prevention of sexual transmission of HIV. Mar. Drugs 2017, 15, 50. [CrossRef]

13. Hu, Z.; Zhang, D.-Y.; Lu, S.-T.; Li, P.-W.; Li, S.-D. Chitosan-based composite materials for prospective hemostatic applications. Mar. Drugs 2018, 16, 273. [CrossRef]

14. Gong, Y.; Tao, L.; Wang, F.; Liu, W.; Jing, L.; Liu, D.; Hu, S.; Xie, Y.; Zhou, N. Chitosan as an adjuvant for a Helicobacter pylori therapeutic vaccine. Mol. Med. Rep. 2015, 12, 4123-4132. [CrossRef] [PubMed]

15. Verlee, A.; Mincke, S.; Stevens, C.V. Recent developments in antibacterial and antifungal chitosan and its derivatives. Carbohydr. Polym. 2017, 164, 268-283. [CrossRef] [PubMed]

16. Chang, S.-H.; Lin, H.-T.V.; Wu, G.-J.; Tsai, G.J. pH Effects on solubility, zeta potential, and correlation between antibacterial activity and molecular weight of chitosan. Carbohydr. Polym. 2015, 134, 74-81. [CrossRef]

17. Singh, D.Y.; Prasad, N.K. Double liposomes mediated dual drug targeting for treatment of Helicobacter pylori infections. Die Pharm.-Int. J. Pharm. Sci. 2011, 66, 368-373.

18. Adeniyi, B.A.; Anyiam, F.M. In vitro anti-Helicobacter pylori potential of methanol extract of Allium ascalonicum Linn. (Liliaceae) leaf: Susceptibility and effect on urease activity. Phytother. Res. Int. J. Devoted Pharmacol. Toxicol. Eval. Nat. Prod. Deriv. 2004, 18, 358-361.

19. Chantarasataporn, P.; Tepkasikul, P.; Kingcha, Y.; Yoksan, R.; Pichyangkura, R.; Visessanguan, W.; Chirachanchai, S. Water-based oligochitosan and nanowhisker chitosan as potential food preservatives for shelf-life extension of minced pork. Food Chem. 2014, 159, 463-470. [CrossRef]

20. Tsai, G.J.; Su, W.H.; Chen, H.C.; Pan, C.L. Antimicrobial activity of shrimp chitin and chitosan from different treatments and application to fish preservation. Fish. Sci. 2002, 68, 170-177. [CrossRef]

21. Chang, S.H.; Chen, C.H.; Tsai, G.J. Effects of chitosan on Clostridium perfringens and application in the preservation of pork sausage. Mar. Drugs 2020, 18, 70. [CrossRef]

22. Hoffman, J. Pharmacological therapy of Helicobacter pylori infection. Semin. Gastrointest. Dis. 1997, 8, 156-163.

23. Chiba, N. Ulcer disease and Helicobacter pylori infection: Current treatment. Evid.-Based Gastroenterol. Hepatol. 2019, 68. [CrossRef]

24. Ramteke, S.; Ganesh, N.; Bhattacharya, S.; Jain, N.K. Amoxicillin, clarithromycin, and omeprazole based targeted nanoparticles for the treatment of H. pylori. J. Drug Target. 2009, 17, 225-234. [CrossRef] [PubMed] 
25. Molnar, B.; Szoke, D.; Ruzsovics, A.; Tulassay, Z. Significantly elevated Helicobacter pylori density and different genotype distribution in erosions as compared with normal gastric biopsy specimen detected by quantitative real-time PCR. Eur. J. Gastroenterol. Hepatol. 2008, 20, 305-313. [CrossRef] [PubMed]

26. Ricci, V.; Zarrilli, R.; Romano, M. Voyage of Helicobacter pylori in human stomach: Odyssey of a bacterium. Dig. Liver Dis. 2002, 34, 2-8. [CrossRef]

27. Wu, T.; Wang, L.; Gong, M.; Lin, Y.; Xu, Y.; Ye, L.; Yu, X.; Liu, J.; Liu, J.; He, S. Synergistic effects of nanoparticle heating and amoxicillin on H. pylori inhibition. J. Magn. Magn. Mater. 2019, 485, 95-104. [CrossRef]

28. Chen, X.; Liu, X.M.; Tian, F.; Zhang, Q.; Zhang, H.P.; Zhang, H.; Chen, W. Antagonistic activities of lactobacilli against Helicobacter pylori growth and infection in human gastric epithelial cells. J. Food Sci. 2012, 77, M9-M14. [CrossRef]

29. Toei, K.; Kohara, T. A conductomeric method for colloid titrations. Anal. Chim. Acta 1976, 83, 59-65. [CrossRef]

30. Tsai, C.-C.; Huang, L.-F.; Lin, C.-C.; Tsen, H.-Y. Antagonistic activity against Helicobacter pylori infection in vitro by a strain of Enterococcus faecium TM39. Int. J. Food Microbiol. 2004, 96, 1-12. [CrossRef]

Publisher's Note: MDPI stays neutral with regard to jurisdictional claims in published maps and institutional affiliations.

(C) 2020 by the authors. Licensee MDPI, Basel, Switzerland. This article is an open access article distributed under the terms and conditions of the Creative Commons Attribution (CC BY) license (http://creativecommons.org/licenses/by/4.0/). 